\title{
A SHORT REVIEW OF THE ANTHELMINTIC ROLE OF MIRAZID
}

\author{
Mostafa YAKOOT*
}

\begin{abstract}
Mirazid ${ }^{\circledR}$ is a patented preparation from a plant that had been used in folk medicine since ancient Egyptians (Myrrh). It was registered in Egypt for the treatment of schistosomiasis and fascioliasis. Over 32 independent studies for efficacy of Mirazid had been reviewed and their results analyzed. The majority of these studies reported higher than $90 \%$ cure rates, that even higher in mixed than single trematodal infections in humans and in farm animals. Only two groups of investigators reported lower cure rates as they used lower doses and estimated cure rates at a shorter period from treatment than recommended by innovators.
\end{abstract}

HEADINGS - Fascioliasis. Schistosomiasis mansoni. Trematoda. Anthelmintics. Plant extracts.

Infections with parasitic helminthes, specially blood, liver and intestinal flukes continue to be a major health problem in many countries in the subtropics and tropics.

Mirazid $\AA$ is a patented special preparation from the oleo-resin of a plant that had been used in folk medicine since the era of ancient Egyptians (myrrh) ${ }^{(2)}$.

It had already been registered by the ministry of health in Egypt, after extensive preclinical, animal and clinical studies including large multicenter phase III human clinical trials in five big university centers proving its safety and efficacy in the treatment of schistosomiasis and fascioliasis ${ }^{(5)}$. Over 32 published and unpublished clinical trials had been done to test efficacy of Mirazid in the treatment of infection by many species of helminthes both in animals and in humans. The greatest majority of these independent studies had reported cure rates higher than $90 \%$ in human clinical trials, as well as in studies on experimentally and naturally infected farm animals ${ }^{(5)}$. Only two groups of investigators reported low cure rates. This had lead to conflicting evidence regarding the efficacy of this newly marketed drug. To solve this conflict we have critically reviewed all published and unpublished studies done on mirazid and tried to reach a conclusion. We found that the high cure rates of over $90 \%$ in case of human infections with schistosomiasis, fascioliasis and other single or mixed parasitic infections were reported with the recommended protocol of using a dose of 10 $\mathrm{mg} / \mathrm{kg}$ body weight with a minimum of $600 \mathrm{mg}$ (two capsules) daily 1 hour before breakfast for 6 successive days. The cure rates as defined by absence of ova in stools were estimated at least 2 or 3 months after the course of treatment, while ova count by kato technique had been repeated monthly for those cases that were still passing ova in stools ${ }^{(5)}$ (Figure 1).

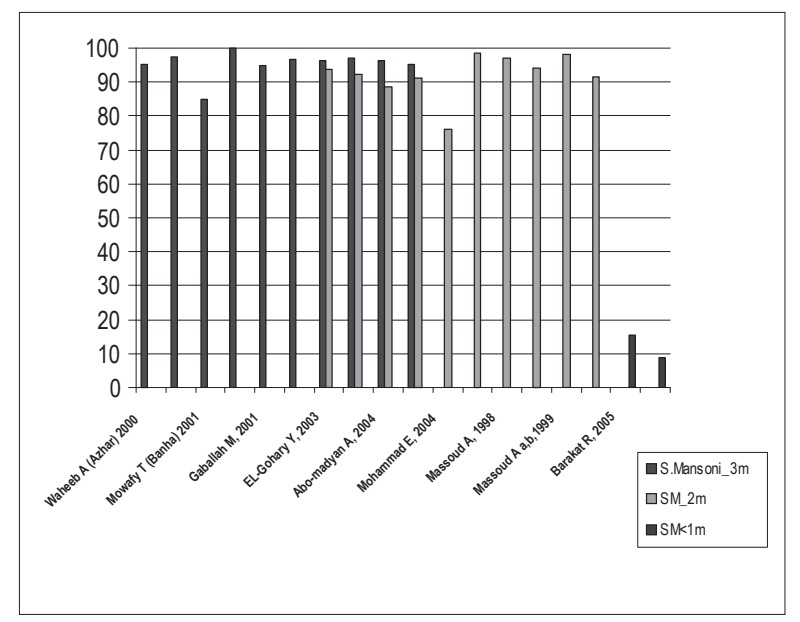

FIGURE 1. \% Parasitological cure (no eggs in stools) rates of S.mansoni at 1,2, 3 moths after Mirazid treatment

For animal studies, the repeatedly tested, protocol with cure rates over $90 \%$ for sheep naturally infected with fascioliasis, dicrocoeliasis, or monieziasis, which is recommended by the innovators, is to use the special veterinary administrable emulsified suspension (offered free by manufacturer for any local or international investigator) in a dose of $6 \mathrm{~mL}, 1$ hour before first feed in the morning for 6 to 8 days. Also as in humans the primary end-point is the cure rate or the worm load reduction, estimated at 2 and 3 months after treatment ${ }^{(5)}$.

While in the studies which reported low cure rates ${ }^{(5)}$, the dose, the duration of treatment and the endpoints were different.

Botros et al. ${ }^{(5)}$ had used a dose of only one capsule $300 \mathrm{mg}$ once daily for 3 days for human patients infected with Schistosoma mansoni. They estimated the cure rates at only 4 to 6 weeks after treatment. While Barakat et 
al. ${ }^{(5)}$ stated that they used mirazid in a dose of two capsules daily for only 3 successive days (not 6 days) and estimated the cure rates at 3 and 4 weeks after treatment.

Botros et al ${ }^{(5)}$ had estimated the reduction in worm loads in ovine fascioliasis at only 4 weeks while it should be at 8 and 12 weeks as recommended by the innovators. They did not mention the batch number of mirazid capsules they used and how they emulsified and administered the capsule contents to animals, in-order to be sure that they did not mistakenly buy the imitated cheaper products in the market with whole myrrh extract which is not equivalent to the patented mirazid preparation manufactured under good manufacturing and quality control practices.

The reason for that had been explained by the results of scanning electron microscopic studies and by hatching and sedimentation tests done by many independent investigators ${ }^{(5)}$. It was found that the adult worms first become contracted and lose their anchorage to the walls, then the process of tegumental destruction and attacking by the immune system take place in a rather smoother and slower curve than the case with chemical comparators, which explained in-part the higher tolerability of mirazid in patients with advanced liver and/or renal disease. This results in excretion of a progressively decreasing egg count over a period that is longer in case of heavy infections and may take up to 3 months for the ova to completely disappear as the adult worms became fully disintegrated. The presence of more than one species of worm infection was also studied. It was found by statistical analysis that the presence of mixed parasitic infection with any of the intraluminal, trematode nematode or cestode worms which proved in other studies to be more responsive to lower Mirazid doses and durations had lead to higher and faster cure rates than single schistosoma or fasciola infection ${ }^{(6)}$. This was explained by the assumption that priming the immune system with more sensitive intestinal worm shared antigens may enhance the process of immune eradication of the more resistant schistosoma or fasciola worms. Also many investigators proved that mirazid extract can act on snails as well as immature forms, thus it can be beneficial as a preventive measure before or following exposure ${ }^{(1)}$.

These facts added to the known high safety and tolerability of myrrh as known from its FDA GRAS (Generally Recognized As Safe) status; complemented with extra-benefits as its proved tumoricidal activity(4), anti-dyspeptic, anti-ulcer, antiinflammatory, anti-hypercholesterolemic, anti-hyperglycemic, as well as anti-bacterial and anti-fungal activities ${ }^{(3)}$ make its benefits much over-weigh its risks, especially in patients with advanced liver or multisystem dysfunctions.

To conclude, it would be conclusive as stated by Southgate et al. ${ }^{(5)}$ that an independent body such as the World Health Organization would organize a multinational study with the right recommended protocol and put guidelines for the treatment of schistosomiasis or fascioliasis and the place of mirazid in such indications.

Yakoot M. Breve revisão sobre a ação anti-helmíntica do mirazid. Arq Gastroenterol. 2010;47(4):393-4

RESUMO - Mirazid ${ }^{\circledR}$ é um produto patenteado preparado a partir de planta usada na medicina popular desde o Egito antigo conhecida como Mirra. Está registrada no Egito para o tratamento da esquistossomose e da fasciolíase. Foram revistos 32 estudos independentes sobre a eficácia do mirazid e seus resultados analisados. A maioria destes estudos reporta mais de $90 \%$ de índice de cura, tanto em infecções mistas por trematódeos em humanos como em animais rurais. Apenas dois grupos de investigadores tiveram baixos índices de cura, mas usaram baixas doses e períodos curtos de tratamento, diferente do recomendado pelos precursores.

DESCRITORES - Fasciolíase. Esquistossomose mansoni. Trematódeos. Anti-helmínticos. Extratos vegetais.

\section{REFERENCES}

1. Allam AF, el-Sayad MH, Khalil SS. Laboratory assessment of the molluscicidal activity of Commiphora molmol (Myrrh) on Biomphalaria alexandrina, Bulinus truncatus and Lymnaea cailliaudi. J Egypt Soc Parasitol. 2001;31:683-90.

2. Buckley SA, Evershed RP. Organic chemistry of embalming agents in Pharaonic and Graeco-Roman mummies. Nature. 2001;413:837-41.

3. Dolara P, Corte B, Ghelardini C, Pugliese AM, Cerbai E, Menichetti S, Lo Nostro A. Local anaesthetic, antibacterial and antifungal properties of sesquiterpenes from myrrh. Planta Med. 2000;66:356-8.
4. Mazzio EA, Soliman KF. In vitro screening for the tumoricidal properties of international medicinal herbs. Phytother Res. 2009;23:385-98.

5. PubMed [Internet]. Bethesda, MD: National Library of Medicine (US); 2002 2010. Mirazid. Available from: http://www.ncbi.nlm.nih.gov/sites/entrez?db=p ubmed\&cmd=DetailsSearch\&term=mirazid

6. Yakoot M. IX European Multicolloquium of Parasitology (EMOP-IX). Oral Presentation: Valencia, Spain, 2004 July 18-23rd., Abstract Book, p 261.

Received 31/5/2010 Accepted 8/6/2010 